\title{
悪性胸膜中皮腫の基本組織型における中皮腫抗原発現の 免疫組織化学的検討
}

Immunohistochemical Studies of Malignant Pleural Mesothelioma using the Mesothelium-related Antigens

泉 浩 ${ }^{1} \cdot$ 熊坂利夫 $^{1} \cdot$ 宮元秀昭 $^{2} \cdot$ 山崎明男 $^{2} \cdot$ 植草利公 $^{3}$

要旨：悪性胸膜中皮腫 28 例（上皮型 19 例，二相型 5 例，肉腫型 4 例）を基本組織型別に中皮腫陽性抗体および接 着因子の発現ならびにその病理診断における有用性を検討した. 対照として肺腺癌 12 例, 限局性胸膜線維腫 5 例を用いた。胸膜中皮腫の各抗体陽性率は calretinin 22/28 (78.6\%), thrombomodulin 10/28（35.7\%）， vimentin 16/28 (57.1\%), CAM5.2 28/28 (100\%)， N-cadherin 26/28 (92.9\%)， E-cadherin 2/28 (7.4\%), および Ber-Ep4 1/28(3.7\%)であった. calretinin は上皮型が 16 例陽性で特に管状乳頭状で染色性が強いが, thrombomodulin の上皮型陽性例は 4 例のみであった. vimentin は二相型，肉腫型で強い染色性を示すが，上 皮型が 7 例のみ陽性であった. 肺腺癌の各抗体陽性率は calretinin, thrombomodulin および vimentin で低く, E-cadherin と Ber-Ep4 では高く, 胸膜中皮腫との間で有意差を認めた. CAM5.2 と N-cadherin は胸膜中皮腫, 肺腺癌ともに高率に陽性を示し診断的意義はなかった。限局性胸膜線維腫は vimentin が全例陽性, calretinin 2 例弱陽性のほかは, CAM5.2, thrombomodulin および Ber-Ep4 はともに陰性であった。 以上より, 悪性胸膜 中皮腫の診断には，calretinin 陽性，Ber-Ep4 陰性およびE-cadherin 陰性が有用と考えられた.

〔肺癌 40 (7) : 711〜 717, 2000, JJLC $40: 711 \sim 717,2000 〕$

Key words : Malignant mesothelioma, Immunohistochemistry, Mesothelium-related antigens, Cadherin-family

はじめに

悪性胸膜中皮腫は，胸膜上に多発小結節状，斑状に出 現し, その後胸腔全体に拡がり, 胸膜肥厚, 周囲組織へ の浸潤がみられる ${ }^{1)-3)}$. 組織像は非常に多彩で, 通常型で は上皮型, 肉腫型, おょび両成分が混在する二相型の 3 つの基本組織型（histological types）に分類され，さらに 各型が組織構造 (patterns) 別に亜分類される ${ }^{1) \sim 4)}$. 本腫 瘍の確定診断は胸膜生検や胸腔鏡下の生検 - 切除標本よ り病理組織学的になされるが, 通常の hematoxylin-eosin (H. E.) 染色のみでは診断に難渋する場合があり, 免疫組 織化学的手法が併用されている. 病理診断に当初用いら れた抗体は，多くが中皮腫に除性を目的とするもので あったが，近年のホルマリン固定パラフィン包埋標本で 利用可能な抗体は，中皮細胞・中皮腫に陽性を示し，同 時に鑑別で問題となる肺腺癌に対しても検討が加えられ ている.しかしながら，これら抗体について中皮腫各基 本組織型における発現性の詳細な検討は少ない. 今回 我々は胸膜中皮腫の基本組織型別に中皮腫陽性抗体であ

\footnotetext{
1. 順天堂大学病理学第一

2. 同 胸部外科

3. 関東労災病院検査部

別刷請求先：泉 浩 順天堂大学病理学第一

于113-8421＼cjkstart東京都文京区本郷 2-1-1

TEL : 03-3813-3111
}

る calretinin, thrombomodulin, 中間径フィラメント,およ び細胞接着因子である cadherin family の発現性を免疫 組織化学的に検討し, 併せてその診断における有用性を 考察したので報告する。

\section{対象と方法}

対象は 1989 年から 1998 年までに順天堂大学, 東京莪 信病院, 三井記念病院, および国立療養所富士病院にお いて病理組織学的に悪性胸膜中皮腫と診断された 28 例 である. 内訳は腫瘍切除 17 例, 剖検 7 例, 胸腔鏡下生検 3 例, および開胸生検 1 例である. 対照として壁側胸膜に 浸潤した肺腺癌 12 例と限局性胸膜線維腫 5 例を用い た.

各症例はホルマリン固定後, 1〜2 個の組織片をパラ フィン包埋とし， $4 \mu \mathrm{m}$ の薄切片に通常の方法で H. E. 染 色などを行った。また Table 1 に示す各種抗体を用いて， Labeled Streptavidin Biotin（LSAB）法（DAKO）または Envision 法 (DAKO) にしたがって免疫組織化学的染色を 行った．染色性は以下のように判定した．すなわち，0 （除性または微量陽性）=腫瘍細胞の $5 \%$ 未満陽性； $1+$ (弱陽性) = 同 $5 \%$ から $25 \%$ 陽性；2+(中等度陽性）= 同 $26 \%$ から $50 \%$ 陽性; $3+$ (強陽性) $=$ 同 $50 \%$ 以上陽 性とした.

統計学的検定は $\chi^{2}$ 独立性の検定及び Fisher の直接確 率計算法を用い，危険率 $5 \%$ 未満 $(\mathrm{p}<0.05)$ をもって有意 
Table 1. Antibodies used in this study

\begin{tabular}{ccclccc}
\hline Antibody & Clone & Source & Dilution & 2nd antibody & Pretreatment \\
\hline Calretinin & polyclonal & Chemicon & $1: 4000$ & LSAB & $95^{\circ} \mathrm{C}$ 20min \\
Thrombomodulin & TM-1009 & DAKO & $1: 800$ & LSAB & $0.1 \%$ Trypsin 30min \\
Vimentin & V9 & DAKO & $1: 200$ & LSAB & $95^{\circ} \mathrm{C}$ & $5 \mathrm{~min}$ \\
Cytokeratins & CAM 5.2 & B.D. & $1: 1000$ & LSAB & $0.1 \%$ Trypsin 30min \\
N-cadherin & polyclonal & Takara & $1: 2000$ & Envision & $95^{\circ} \mathrm{C}$ 20min \\
E-cadherin & HECD-1 & Takara & $1: 1000$ & Envision & $95^{\circ} \mathrm{C}$ & $20 \mathrm{~min}$ \\
Ber-Ep4 & Ber-Ep4 & DAKO & $1: 1000$ & LSAB & $0.1 \%$ Trypsin 30min \\
\hline
\end{tabular}

B.D., Becton Dicknson ;

Table 2. The histological types and patterns of malignant mesothelioma

\begin{tabular}{|c|c|c|c|c|c|c|}
\hline Types & Epithelial & $(n=19)$ & Biphasic & $(\mathrm{n}=5)$ & Sarcomatous & $(\mathrm{n}=4)$ \\
\hline \multirow{4}{*}{ Patterns } & Tubulopapillary & 10 & $\begin{array}{l}\text { Tubulopapillary } \\
\text { + Fibroblastic }\end{array}$ & 2 & \multirow[t]{4}{*}{ Fibroblastic } & \multirow[t]{4}{*}{4} \\
\hline & $\begin{array}{l}\text { Tubulopapillary } \\
+ \text { Microglandular }\end{array}$ & 3 & $\begin{array}{l}\text { Tubulopapillary } \\
+ \text { Desmoplastic }\end{array}$ & 1 & & \\
\hline & $\begin{array}{l}\text { Tubulopapillary } \\
\text { + Pleomorphic }\end{array}$ & 2 & $\begin{array}{l}\text { Solid } \\
+ \text { Fibroblastic }\end{array}$ & 2 & & \\
\hline & Solid & 4 & & & & \\
\hline
\end{tabular}

Table 3. Immunoreactivity of mesothelium related antigens, intermediate filaments and N-cadherin for mesothelioma

\begin{tabular}{|c|c|c|c|c|c|c|}
\hline \multirow{2}{*}{ Antigen } & \multirow{2}{*}{ Types } & \multirow{2}{*}{$\begin{array}{l}\text { positive } \\
\text { cases }\end{array}$} & \multicolumn{4}{|c|}{ immunoreactivity } \\
\hline & & & 0 (Trace) & $1+$ & $2+$ & $3+$ \\
\hline \multirow[t]{4}{*}{ Calretinin } & epithelial & $16 / 19$ & 3 & 3 & 3 & 10 \\
\hline & biphasic & $3 / 5$ & 2 & 1 & $2 ※$ & 0 \\
\hline & sarcomatous & $3 / 4$ & 1 & 2 & 0 & 1 \\
\hline & total & $22 / 28$ & & & & \\
\hline \multirow[t]{4}{*}{ Thrombomodulin } & epithelial & $4 / 19$ & 15 & 1 & 1 & 2 \\
\hline & biphasic & $4 / 5$ & 1 & 3 & $1 ※$ & 0 \\
\hline & sarcomatous & $2 / 4$ & 2 & 1 & 1 & 0 \\
\hline & total & $10 / 28$ & & & & \\
\hline \multirow[t]{4}{*}{ Vimentin } & epithelial & $7 / 19$ & 12 & 2 & 4 & 1 \\
\hline & biphasic & $5 / 5$ & 0 & 1 & 2 & 2 \\
\hline & sarcomatous & $4 / 4$ & 0 & 0 & 2 & 2 \\
\hline & total & $16 / 28$ & & & & \\
\hline \multirow[t]{4}{*}{ Cytokeratins } & epithelial & $19 / 19$ & 0 & 4 & 5 & 10 \\
\hline & biphasic & $5 / 5$ & 0 & 1 & 2 & 2 \\
\hline & sarcomatous & $4 / 4$ & 0 & 1 & 3 & 0 \\
\hline & total & $28 / 28$ & & & & \\
\hline \multirow[t]{4}{*}{ N-cadherin } & epithelial & $18 / 19$ & 1 & 6 & 7 & 5 \\
\hline & biphasic & $4 / 5$ & 1 & 3 & 1 & 0 \\
\hline & sarcomatous & $4 / 4$ & 0 & 2 & 1 & 1 \\
\hline & total & $26 / 28$ & & & & \\
\hline
\end{tabular}

※ positive only epithelial component

とした。

\section{結 果}

（1）組織形態学的分類 (Table 2)

対象とした悪性胸膜中皮腫 28 例は，肺癌取扱規約改 訂第 5 版 ${ }^{4)}$ および Attanoos $ら^{1)}$ と Gibbs ${ }^{2)}$ の基本組織型 （histological types）にしたがって上皮型 19 例 (67.9\%), 二相型 5 例 $(17.8 \%)$ および肉腫型 4 例 $(14.3 \%)$ に分類 された。組織構造 (patterns) では, 上皮型 19 例は主に 立方状の細胞が乳頭状または乳頭・管状に増殖する管状 乳頭状（Tubulopapillary）15 例と好酸性の細胞がシート 
Fig. 1. Immunohistochemical staining of mesothelioma for calretinin, showing diffuse immunoreactivity in the cytoplasm. (A. epithelial type B. sarcomatous type)

A)

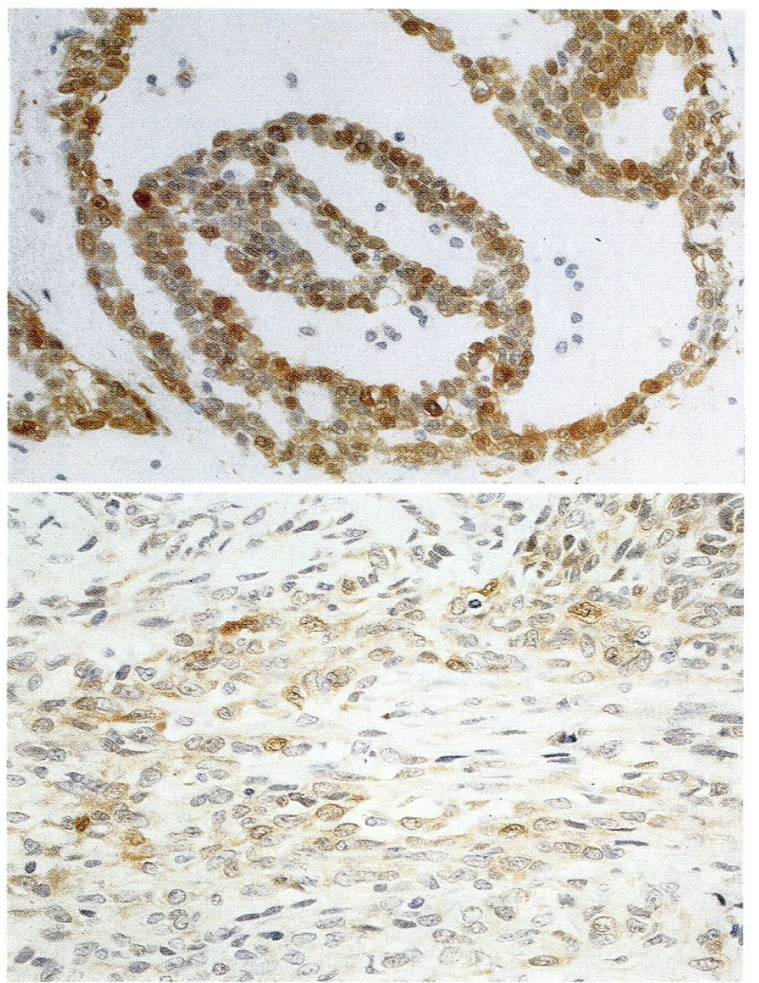

Fig. 2. Immunohistochemical staining of mesothelioma for thrombomodulin, showing linear immunoreactivity on the cell membrane (A. epithelial type B. sarcomatous type)

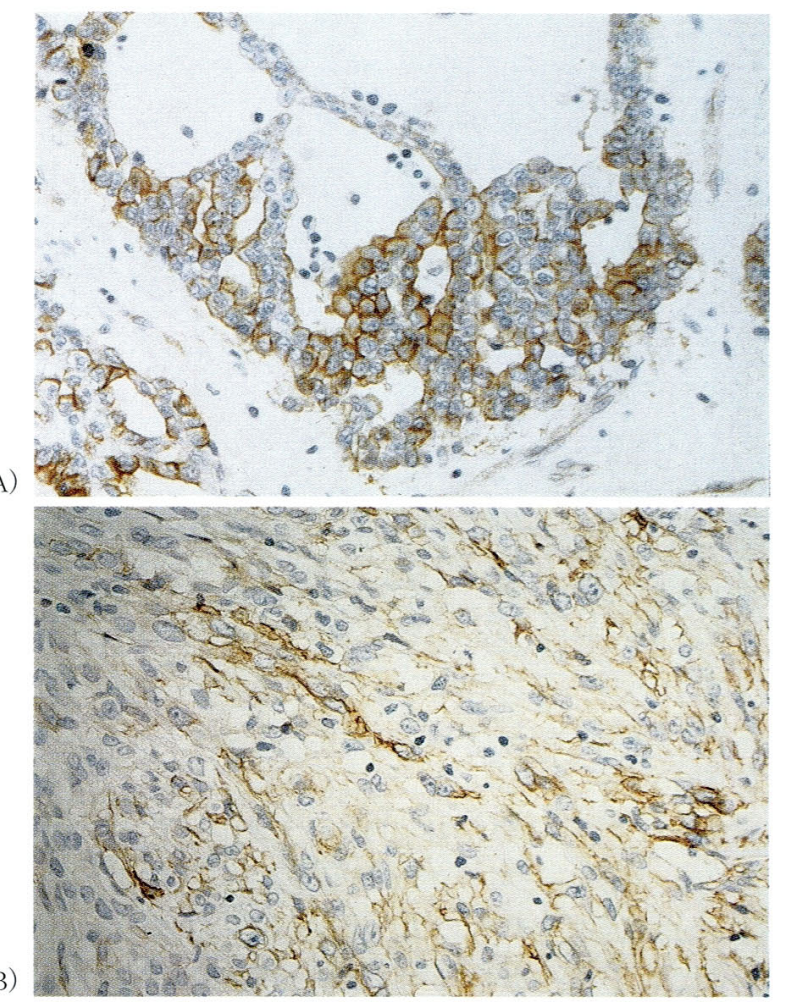

状に増殖する充実性（solid）４例に亜分類された。さらに 管状乳頭状 15 例中 5 例には立方および扁平な細胞が多 数の小腔を形成して増殖する小囊胞状 (microglandular) 3 例，および多形核の細胞が充実性に増殖する多形性 (pleomorphic) 2 例の混在がみられた。二相型 5 例は，上 皮成分が管状，乳頭状または充実性を示し，また肉腫成 分は紡錘型細胞が束状に増殖した線維肉腫性（fibroblastic）または膠原線維束の間に腫崵細胞を認める線維形成 性 (desmoplastic) を示し, それぞれが混在して管状乳頭 状＋線維肉腫性 2 例, 管状乳頭状 + 線維形成性 1 例, お よび充実性＋線維肉腫性 2 例に亜分類された。肉腫型 4 例はすべて線維肉腫性であった。

(2) 免疫組織化学的検討 (Table 3)

1）悪性胸膜中皮腫

a. Mesothelial related antigens

calretinin は中皮腫 28 例中 22 例（78.6\%）の細胞質に 陽性を示した。組織型別では上皮型が 19 例中 16 例陽性 で，うち 10 例が管状乳頭状部分に強陽性を示した（Fig. 1A)，充実性や小囊胞状は中等度から弱陽性であった。陰 性例は, 充実性 2 例, 管状乳頭状+多形性 1 例であった。 二相型は 3 例陽性で, うち 2 例が管状乳頭状部分のみに 中等度陽性であった。肉腫型は 3 例陽性でうち 1 例が強 陽性であった（Fig. 1B）。以上のように calretinin は上皮

型の管状乳頭状で染色性が強い傾向にあった.

thrombomodulin は 10 例 $(35.7 \%)$ の細胞膜に陽性で あったが，上皮型は 4 例のみ陽性で，うち管状乳頭状 3 例が中等度以上陽性，充実性 1 例が弱陽性であった（Fig， $2 A)$. 二相型は 4 例陽性で上皮成分の亜型は管状乳頭状, 充実性各 2 例であり，このうち 3 例は上皮成分の染色性 が肉腫成分より強い傾向にあった。肉腫型は 2 例陽性で あった（Fig. 2A）。

b. Intermediate filaments

上皮性フィラメントである低分子量 cytokeratin CAM 5.2 は中皮腫 28 例全例が細胞膜から細胞質に陽性で，特 に上皮型 10 例が強陽性を示した。間葉系フィラメント である vimentin は 16 例 $(57.1 \%)$ が細胞質に陽性で，う ち二相型，肉腫型が全例陽性を示し，かつ多くが中等度 から強陽性であったのに刘し，上皮型は管状乳頭状 4 例 と管状乳頭状 + 小囊胞状, 管状乳頭状 + 多形性, および 充実性の各 1 例, 計 7 例が陽性で残りの 12 例が陰性で あった。

c. Cadherin family

N-cadherin は26 例 (92.9\%) 陽性で，上皮型，二相型， 肉腫型ともに腫瘍細胞の細胞質に陽性を示した。上皮細 胞の接着因了である E-cadherin は上皮型と二相型上皮 
Table 4. Immunopositivity of mesothelium related antigens, intermediate filaments, Ber-Ep4 and cadherin in mesothelioma, adenocarcinoma and solitary fibrous tumor (S.F.T.)

\begin{tabular}{|c|c|c|c|c|c|c|}
\hline & \multicolumn{4}{|c|}{ mesothelioma $(n=28)$} & \multirow{2}{*}{$\begin{array}{l}\text { adeno ca. } \\
(\mathrm{n}=12)\end{array}$} & \multirow{2}{*}{$\begin{array}{l}\text { S.F.T. } \\
(n=5)\end{array}$} \\
\hline & $\begin{array}{c}\text { epithelial } \\
(\mathrm{n}=19)\end{array}$ & $\begin{array}{l}\text { biphasic } \\
(\mathrm{n}=5)\end{array}$ & $\begin{array}{l}\text { sarcomatous } \\
\quad(n=4)\end{array}$ & $\begin{array}{c}\text { total } \\
\text { positivity }\end{array}$ & & \\
\hline calretinin & 16 & 3 & 3 & $22(78.6 \%) *$ & $2(16.7 \%)$ & $2(40 \%)$ \\
\hline thrombomodulin & 4 & 4 & 2 & $10(35.7 \%) *$ & 0 & 0 \\
\hline vimentin & 7 & 5 & 4 & $16(57.1 \%) *$ & $2(16.7 \%)$ & $5(100 \%)$ \\
\hline Cytokeratins & 19 & 5 & 4 & $28(100 \%)^{\dagger}$ & $12(100 \%)$ & 0 \\
\hline N-cadherin & 18 & 4 & 4 & $26(92.9 \%)$ & $10(83.3 \%)$ & N.D. \\
\hline E-cadherin & 1 & 1 & 0 & $2(7.4 \%)^{*}$ & $8(66.7 \%)$ & N.D. \\
\hline Ber-Ep4 & 1 & 0 & 0 & $1(3.7 \%) *$ & $10(83.3 \%)$ & 0 \\
\hline
\end{tabular}

(\%), positivity rate

Significant difference in positive rate $(\mathrm{p}<0.05)$

* between mesothelioma and adeno ca.

${ }^{\dagger}$ between mesothelioma and S.F.T.

成分の各 1 例が弱陽性であるほかは陰性であった.

d. Epithelial glycoproteins

抗上皮抗体である Ber-Ep4 は上皮型 1 例（8.3\%）のみ が中等度陽性であった。

2）肺腺癌

肺腺癌 12 例（高分化型 8 例, 低分化型 4 例）における calretinin は高分化型 2 例 (16.7\%)のみが弱陽性, thrombomodulin は全例陰性であった. cytokeratin CAM5.2 は 全例陽性, vimentin は高分化型の胸膜浸潤部において 2 例 $(16.7 \%)$ が陽性であった。

E-cadherin は 12 例中 8 例 $(66.7 \%)$ が細胞膜に中等度 陽性で，また N-cadherin は 10 例（83.3\%）が細胞質に中 等度から弱陽性を示した. Ber-Ep4 は高分化型 2 例を除 く 10 例 (83.3\%) が細胞膜に中等度から強陽性であった。

\section{3）限局性胸膜線維腫}

calretinin は2 例で腫瘍細胞に弱陽性であったが, thrombomodulin は全例陰性であった. vimentin は全例強 陽性であったのに対し， cytokeratin CAM5.2 および BerEp4 は全例陰性であった.

（3）中皮腫と肺腺癌および胸膜線維腫との鑑別（Table 4)

中皮腫陽性抗体である calretinin, thrombomodulin お よび vimentin は肺腺癌との陽性率で有意差が認められ た。このうち calretinin は肺腺癌の鑑別対象となる上皮 型中皮腫に高い陽性率と強い染色性を示したが，thrombomodulin や vimentin はその陽性率が高くなかった. cytokeratin CAM 5.2 と N-cadherin は中皮腫で高い陽性率 を示したが肺腺癌においても同様に高く, 有意差がみら れなかった。中皮腫陽性率の低いBer-Ep4, E-cadherin は肺腺癌では陽性率が高く，有意差が認められた。胸膜 線維腫は cytokeratin CAM 5.2 が全例陰性を示し, 中皮腫 との陽性率で有意差が認められた。

\section{考 察}

今回対象とした悪性胸膜中皮腫の 28 例は，上皮型 19 例 $(67.9 \%)$ ，二相型 5 例 $(17.8 \%)$ ，および肉腫型 4 例 (14.3\%) に分類された。これはAttanoos ら ${ }^{1)}$ ，佐々木ら ${ }^{6)}$ のそれぞれ約 50〜 55\%，約 30〜35\%，約 10〜20\% と比 べ上皮型が若干多く，二相型が少なかった. 上皮型が多 いのは，組織内石綿線維数が $1 / 10$ 以下とともに 1989 年以後にみられた中皮腫の傾向である5. また上皮型の 19 例中 15 例が管状乳頭状を示したが，これは最も高頻 度にみられる組織構造である113)6.

肺癌取扱規約改訂第 5 版 ${ }^{4}$ によると中皮腫の病理診断 に役立つ陽性抗体として keratin, vimentin, EMA, HBME1, calretinin, thrombomodulin が挙げられている. しかし 前 3 者は特異性に久け，HBME-1 も中皮細胞に対するモ ノクローナル抗体であるが腺癌にも高率に陽性を示し, 鑑別診断に有用性がない( ${ }^{7) \sim 9)}$. 後 2 者の calretinin ${ }^{10) \sim 12)}$, thrombomodulin ${ }^{6) \sim 9) 13) \sim 15)}$ はその特異性により，多くは上 皮型中皮腫において有用性が報告されている。

今回検討した mesothelium related antigens のうち, calretinin の中皮腫陽性率は 78.6\% で，組織型 (histological types) 別では，特に上皮型で高頻度に強陽性を示し， 二相型や肉腫型でも中等度から弱陽性を示した。これら の成績は従来の全例陽性とする報告 ${ }^{10)}$ 12) と比較し，陽性 率が 100\% ではなかったが，上皮型の染色性が強い点で は一致した。すなわち，Doglioni ら ${ }^{10)}$ は，胸膜中皮腫 44 例（上皮型 36 例，二相型 5 例，肉腫型 3 例）を検討し, calretinin が全例陽性で，特に上皮型の染色性が強く，二 相型でも上皮成分が肉腫成分より染色性が強かったとし ている. Ordóñez ${ }^{11)}$ 七皮型の胸膜中皮腫 38 例全例が陽 性であった．今回，上皮型をさらに組織構造（patterns） 別に検討すると，管状乳頭状がほぼ 100\% 陽性でかつ染 色性も強い傾向にあったのに対し, 充実性は半数の 2 例 が陰性であった. 二相型でも上皮成分の管状乳頭状部分 
が中等度陽性であった，以上より， calretinin は中皮腫上 皮型, 特に分化の高い組織構造に対し強い染色性を持つ と考えられた。

thrombomodulinの中皮腫陽性率は35.7\%で calretinin と比べて低く，しかも上皮型は 4 例のみ陽性で あった。二相型, 肉腫型は上皮型よりやや陽性率が高い ものの，強陽性を示す症例はなく，さらに二相型上皮成 分の染色性が肉腫成分より強い傾向にあった。これらは 従来の上皮型および二相型中皮腫の陽性率が 49.1\% $100 \%{ }^{6) \sim 1013) \sim 15)}$ とする報告より低率で，また佐々木ら ${ }^{6)}$ Attanoos $ら^{7)}$ の上皮型が二相型, 肉腫型より染色性があ るとするのと異なった. thrombomodulin は, 通常中皮腫 細胞膜に陽性となるが，細胞質にも陽性を示すとの報告 もあり ${ }^{14)}$ ，染色法や陽性判定基準により成績に大きく影 響がでるものと考えられた．今回，上皮型陽性例を組織 構造別にみると管状乳頭状 2 例が強陽性であったが, 陽 性例が少ないため thrombomodulin の組織分化度による に違いについては明らかにできなかった。

中間径フィラメントは低分子量 cytokeratin CAM 5.2 が全例陽性であったのに対し, vimentin が組織型で染色 性に違いがあり，二相型・肉腫型の多くが中等度から強 陽性を示したが，上皮型では半数以上が㓌性であった。 Mayall ら ${ }^{16)}$ も vimentin 陽性率が上皮型 54\%，二相型 74 $\%$, 肉腫型 $87 \%$ と組織型で差があるとしており, 佐々木

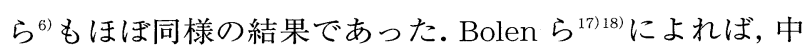
皮下層の間葉系細胞は反応性に増殖すると低分子量 cytokeratin と vimentin の両者に陽性となり, これらが表層 の中皮細胞に分化するに従い, vimentin が染色性を失い, かつ上皮型中皮腫は表面の中皮細胞に, 肉腫型は増殖し た中皮下層の間葉系細胞に類似すると説明した．上皮型 の組織構造では佐々木ら $\left.{ }^{6}\right)$ は分化度の低い構造で陽性率 が高いと報告しているが，今回の上皮型にはいずれの組 織構造でも陽性例があり, 腫瘍の組織分化度と vimentin との発現性の関連は認められなかった。

対照例とした肺腺癌の各抗体陽性率は, calretinin, thrombomodulin および vimentin が低く, これに対し Ecadherin と Ber-Ep4 が高率で, 胸膜中皮腫との間で有意 差を認めた。しかし, cytokeratin CAM5.2 と N-cadherin は中皮腫, 肺腺癌ともに陽性率が高く診断的意義がな かった.これらの成績は, calretininについて Doglioni $ら^{10)}$ の肺腺癌 40 例中 9 例, Ordóñez $z^{11}$ 野同 38 例中 3 例が それぞれ弱陽性を示したのとほぼ一致した. thrombomodulin は, 肺腺癌に陽性例がないため, 上皮型中皮腫で は陰性のことが多かったにもかかわらず，特異性が明ら かであった. vimentin は肺腺癌で陽性を示すことがあ

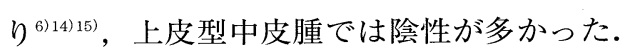

細胞接着因子 cadherin は, Solar ${ }^{19)}, \operatorname{Han} ら^{20)}$ により, 胸 膜中皮腫が神経細胞の接着因子である N-cadherin に, 肺
腺癌が上皮細胞の接着因子である E-cadherin にそれぞ れの細胞膜が免疫反応を示すことが証明され, その発現 の違いが両者の鑑別に有用であると報告された. しかし， 今回の検討では E-cadherin は彼らのそれと一致したが, N-cadherin では異なって, 中皮腫, 肺腺癌ともに細胞質 が陽性となった。この相違は, 彼らの検討が生検や cell blockのホルマリン固定標本を用いており ${ }^{20)}$, それは今 回使用した標本に比べ, 抗体に対する感受性, 特異性が 良好であることが考えられた。

以上の検討から中皮腫に陽性を示す抗体は calretinin が高率であり，かつ肺腺癌に対して低率という特異性を 有し, 最も有用であると考えられた。しかし上皮型でも 分化の低い組織構造では染色性が弱いことがあり, 判定 に難渋すると考えられる.従来より肺腺癌との鑑別では, 中皮腫に陰性, 肺腺癌に陽性を示す抗体 ${ }^{4)}$ とて CEA, Leu-M1, B72.3, Ber-Ep4 が使用されている. Garcia-prats $ら^{21)}$ は過去の検討例を集計し, 中皮腫に陰性抗体のうち Ber-Ep4 が肺癌組織の陽性率が高く鑑別診断に一番有用 であると報告している．また今回の結果から E-cadherin も中皮腫陰性抗体として鑑別に有用であると考えられ た.よって肺腺癌との鑑別診断には中皮腫に陽性を示す calretinin とともに陰性を示す Ber-Ep4 や E-cadherin を 組み合わせた検討が有用である.

限局性胸膜線維腫は線維芽細胞様の腫瘍細胞と膠原線 維からなり, 組織学的に悪性胸膜中皮腫の二相型または 肉腫型との鑑別が問題となる. 免疫組織化学的には今回 の検討を含め腫瘍細胞は cytokeratin CAM5.2 に陰性, か つ CD34に陽性 22 223) であることが中皮腫との鑑別に有用 である。

\section{結 論}

悪性胸膜中皮腫の calretinin の陽性率は $78.6 \%$ と高 く, 特に上皮型の分化の高い組織構造に染色性が強かっ た. thrombomodulin の陽性率は $35.7 \%$ で上皮型陽性例 が少なかった. vimentinの陽性率は $57.1 \%$ で, 上皮型中 皮腫で陰性例が多かった. 肺腺癌との鑑別には calretinin 陽性，上皮抗体である Ber-Ep4 陰性，および E-cadherin 陰性が有用所見であった。

本論文の要旨は第 39 回日本肺癌学会 (1998 年 10 月, 金沢), 第 88 回日本病理学会 (1999 年 4 月, 東京), 第 16 回日本呼吸器外科 学会（1999 年 5 月, 東京)にて発表した.

謝 辞 : 稿を終えるにあたり, 順天堂大学病理学第一須田耕一教 授, 同胸部外科細田泰之教授, 東京逓信病院呼吸器外科益田貞彦部 長, 同病理部薬丸一洋部長, 三井記念病院呼吸器外科羽田圓城部長, 坂口浩三先生, 同病理部高梨利一郎部長, 国立療養所富士病院副院 長石原重樹先生及び順天堂大学病理学第一三谷恵子技師に紙面を 扮借りして深謝致します。 
1) Attanoos RL, Gibbs AR : Pathology of malignant mesothelioma. Histopathology 30 : 403-418, 1997.

2) Gibbs AR, Whimster WF : Tumors of the lung and pleura. In : Fletcher CDM, ed. Diagnostic Histopathology of Tumors, Volume 1. Churchill Livingstone, Edinburgh, pp 127$150,1995$.

3) Battifora H, McCaughey WTE : Diffuse malignant mesothelioma. In : Atlas of Tumour Pathology, 3rd series, fascicle 15. Armed Forces Institute of Pathology, Washington. DC, pp 17-88, 1995.

4）日本肺癌学会/編：悪性胸膜中皮腫の組織形態. 肺癌取扱 い規約，改訂第 5 版. 東京, 金原出版, 124-139 頁, 1999.

5）片山正一, 中野喜久雄, 平本雄彦, 他：増加する悪性中皮 腫一石綿高度曝露地域からの報告一. 肺癌 $37: 23-31$, 1997.

6）佐々木正道, 北川正信, 森永謙二：びまん性悪性胸膜中皮 腫の病理一大阪中皮腫パネル 117 例の検討一. 病理と臨 床 $17: 1111-1116,1999$.

7) Attanoos RL, Goddard H, Gibbs AR : Mesotheliomabinding antibodies : thrombomodulin, OV 632, and HBME1 and their use in the diagnosis of mesothelioma. Histopathology 29 : 209-215, 1996.

8) Ordóñez NG : The value of antibodies 44-3 A 6, SM 3, HBME-1, and Thrombomodulin in differentiating epithelial pleural mesothelioma from lung adenocarcinoma. A comparative study with other commonly used antibodies. Am J Surg Pathol 21 : 1399-1408, 1997.

9) Kennedy AD, King G, Kerr KM : HBME-1, and antithrombomodulin in the differential diagnosis of malignant mesothelioma of pleura. J Clin Pathol 30 : 859-862, 1997.

10) Doglioni C, Dei Tos AP, Laurino L, et al : Calretinin : A novel immunocytochemical marker for mesothelioma. Am J Surg Pathol 20 : 1037-1046, 1996.

11). Ordóñez NG : Value of calretinin immunostaining in differentiating epithelial mesothelioma from lung adenocarcinoma. Mod Pathol 11 : 929-933, 1998.

12) Leers MPG, Aarts MMJ, Theunissen PHMH : E-cadherin and calretinin : a useful combination of immunochemical markers for differentiation between mesothelioma and metastatic adenocarcinoma. Histopathology 32 : 209-216, 1998.

13) Collins CL, Ordóñez NG, Schaefer R, et al : Thrombomodulin expression in malignant pleural mesothelioma and pulmonary adenocarcinoma. Am J Pathol 141 : 827833, 1992

14) Riera JR, Astengo-Osuna C, Longmate JA, et al : The immunohistochemical diagnostic panel for epithelial mesothelioma, A reevaluation after heat-induced epitope retrieval. Am J Surg Pathol 21 : 1409-1419, 1997.

15) Brown RW, Clark GW, Tnadon AK, et al : Multiple-marker immunohistochemical phenotypes distinguishing malignant pleural mesothelioma from pulmonary adenocarcinoma. Hum Pathol 24 : 347-354, 1993.

16) Mayall $F G$, Goddard $H$, Gibbs $A R$, et al : Intermediate filament expression in mesotheliomas : leiomyoid mesothelioma are not uncommon. Histopathology 21 : 453-457, 1992.

17) Bolen JW, Hammar SP, McNutt MA : Reactive and neoplastic serosal tissue : A light-microscopic, ultrastructural, and immunocytochemical study. Am J Surg Pathol 10 : 3447, 1986.

18) Hammar SP : Pleural disease. In : Dail DH, Hammar SP, eds. Pulmonary Pathology, 2nd ed. Springer-Verlag, New York, pp 1463-1579, 1994.

19) Peralta Soler A, Knudsen KA, Jaurand MC, et al : The differential expression of N-cadherin and E-cadherin distinguishes pleural mesothelioma from lung adenocarcinoma. Hum Pathol 26 : 1363-1369, 1995.

20) Han AC, Peralta Soler A, Knudsen KA, et al : Differential expression of $\mathrm{N}$-cadherin in pleural mesotheliomas and $\mathrm{E}$ cadherin in lung adenocarcinoma in formalin-fixed, paraffin-embedded tissues. Hum Pathol 28 : 641-645, 1997.

21) Garcia-prats MD, Ballestin C, Sotelo T, et al : A comparative evaluation of immunohistochemical markers for the differential diagnosis of malignant pleural tumours. Histopathology 32 : 462-472, 1998.

22) Flint A, Weiss SW : CD-34 and keratin expression distinguishes solitary fibrous tumor (fibrous mesothelioma) of pleura from desmoplastic mesothelioma. Hum Pathol 26 : 428-431, 1995

23) Hanau CA, Miettinen M : Solitary fibrous tumor : histological and immunohistochemical spectrum of benign and malignant variants presenting at different sites. Hum Pathol $26: 440-449,1995$ 


\title{
Immunohistochemical Studies of Malignant Pleural Mesothelioma using the Mesothelium-related Antigens
}

\author{
Hiroshi Izumi ${ }^{1}$, Toshio Kumasaka ${ }^{1}$, Hideaki Miyamoto', \\ Akio Yamazaki ${ }^{2}$ and Toshimasa Uekusa ${ }^{3}$
}

1. Department of First Pathology and

2. Thoracic Surgery, Juntendo University, School of Medicine, Tokyo, Japan

3. Department of Laboratory, Labour Welfare Corporation Kanto Rousai Hospital, Kawasaki, Japan

Objectives : We examined immunoreactivity for mesothelium-related antigens and cadherin-family antigens in different histological types of malignant mesothelioma of the pleura.

Methods : In 28 cases (19 epithelial type, 5 biphasic type and 4 sarcomatous type) these antibodies were investigated in terms of efficiency of diagnosis of mesothelioma. Controls consisted of 12 cases of pulmonary adenocarcinoma and 5 cases of solitary fibrous tumor. Results : The immunoreactivity rates in mesothelioma for each antigen were as follows : 22 /28 (78.6\%) for calretinin, 10/28 (35.7\%) for thrombomodulin, 16/28 (57.1\%) for vimentin, 28/28 (100\%) for CAM $5.2,26 / 28(92.9 \%)$ for N-cadherin, 2/28 (7.1\%) for E-cadherin and 1/28 (3.6\%) for Ber-Ep4. Sixteen cases of the epithelial type were positive for calretinin, and, in particular cases of tubulopapillary pattern were strongly positive. On the other hand, only four cases of the epithelial type were positive for thrombomodulin. All of biphasic and sarcomatous type cases were strongly positive for vimentin, whereas only 7 cases of the epithelial type were positive. In adenocarcinoma, the positivity rate was low for calretinin, thrombomodulin and vimentin, whereas it was high for E-cadherin and Ber-Ep4 ; a significant difference in the positivity rate for calretinin, thrombomodulin, vimentin, E-cadherin and Ber-Ep4 being clearly observed between adenocarcinoma and mesothelioma. However, both mesothelioma and adenocarcinoma were highly positive for CAM5.2 and N-cadherin, suggesting little diagnostic efficiency. All cases of solitary fibrous tumor were positive for vimentin and two of these cases were weakly positive for calretinin. However, all cases of solitary fibrous tumor were negative for CAM5.2, thrombomodulin and Ber-Ep4.

Conclusion : Our results suggested that not only positive immunoreactivity for calretinin but also negative immunoreactivity for Ber-Ep4 and E-cadherin were important for the diagnosis of malignant mesothelioma.

〔JJLC 40 : 711 717, 2000〕 